\title{
Chapter 18 \\ Diaspora Policies, Consular Services and Social Protection for Lithuanian Citizens Abroad
}

\author{
Dangis Gudelis and Luka Klimavičiūtė
}

\subsection{Introduction}

This chapter focuses on diaspora and consular policies developed by the Lithuanian authorities and their response to the social protection needs of citizens living abroad. The first part of the chapter presents the general institutional framework by which the Lithuanian authorities interact with the nationals residing in a foreign country as well as the main engagement policies for the diaspora. The second part focuses on the policies, programmes and services offered by the Lithuanian authorities to respond to the social protection needs of the nationals living abroad across five specific policy areas: economic hardship, unemployment, health care, pensions, and family-related benefits. Although Lifvthuania has been proactive in maintaining relations with its diaspora since 2011, there is a lack of social services for emigrants because of the public opinion that Lithuanians abroad are in a better financial position to contribute rather than benefit from the limited state budget.

D. Gudelis $(\bowtie)$

Mykolas Romeris University, Vilnius, Lithuania

e-mail: dgudel@mruni.eu

L. Klimavičiūtè

Public Policy and Management Institute, Vilnius, Lithuania

e-mail: luka.klimaviciute@ richmond.edu 


\subsection{Diaspora Policy Infrastructure and Key Policies}

\subsubsection{Lithuanian Diaspora and Relations with the Homeland}

The Lithuanian diaspora, which includes persons of the Lithuanian origin living outside of Lithuania, numbers 619,600 (i.e. $16.9 \%$ of the total population of Lithuania). The major countries of residence of Lithuanians are the United Kingdom (U.K, $19.9 \%$ of the total diaspora population), Russia (13.6\%), Poland (10\%), Canada (7.9\%), Germany (7\%), Ireland (6.4\%), and the United States (U.S, 5.8\%) (Department of Statistics of the Republic of Lithuania 2014).

Researchers identify three waves of emigration from Lithuania that resulted in the formation of the modern Lithuanian diaspora (Čiubrinskas 2005, p. 80). The first wave of emigration refers to those Lithuanians who moved from the Russian empire looking for a better life in the United States of America, Australia, or South America between the second half of the nineteenth century and the beginning of the twentieth century. This trend of emigration lasted until the first Soviet occupation in 1940. The Lithuanian diaspora of the first wave was active in social and cultural life: many Lithuanian societies, charities, and newspapers were established in this period of time. The diaspora contributed to building political, economic, and social institutions of the Republic of Lithuania during its Independence between 1918 and 1940.

The second wave of emigration from Lithuania started at the end of World War II. Many Lithuanians - mainly the political, economic, and cultural elite - migrated to escape the repressions of the Soviet regime. Until 1950, they were settled in refugee camps (displaced persons' camps) in the West Germany and after receiving immigration permits, many of them moved to the United States of America, Canada, Australia, or the United Kingdom. The major reason of the second wave of emigration was political, thus shaping the identity of this generation of the Lithuanian diaspora. Emigrants of that wave established political and civic organizations that played a significant role in the political processes leading to the restoration of Lithuania's independence in 1990.

In the last decade of the twentieth century, after the Restoration of Independence, the third wave of emigration from Lithuania was mainly due to economic reasons. This outflow intensified after Lithuania joined the European Union (EU) and the Schengen zone in 2004 and the major destination countries were the United Kingdom, Ireland, and Norway. During this third wave of emigration, mostly younger people decided to leave Lithuania (in 2013, 31.6\% of emigrants were between 25 and 34 years old, and $26.3 \%$ emigrants were in the age group of 15-24 years) (Gudelis and Klimavičiūtè 2016, p.1). A recent survey (Vilmorus 2018) confirmed that many emigrants move abroad for economic reasons: $24 \%$ of the respondents moved for higher salaries or because they could not find work in Lithuania, while $15 \%$ cited better career prospects abroad. Nevertheless, roughly one out of five survey participants said they had moved for family reasons, $17 \%$ for studies and another $15 \%$ sought to change their lifestyle. Thus, non-economic reasons also play a role in migration decisions. 
The economic nature of the third wave of emigration explains why social protection for emigrants is limited. Given that most migrants move to more affluent countries, in Lithuania they are perceived as a source of financial assistance rather than individuals in need. Many Lithuanian migrants also send remittances (Gudelis and Klimavičiūtè 2016), thus strengthening this image. This perception might be slowly changing: the Parliament of the Republic of Lithuania is considering a law that would provide assistance for people with Lithuanian heritage to return to Lithuania from countries that face instability such as Venezuela. ${ }^{1}$

\subsubsection{Diaspora Infrastructure}

To engage with the diaspora and respond to its needs, the Governments of the Republic of Lithuania established various institutions. The Ministry of Foreign Affairs (MFA), established in 1990, is the major institution responsible for diaspora engagement. Strengthening relationships with Lithuanians living abroad is one of the objectives set in MFA's statute. ${ }^{2}$ The functions related to the implementation of this goal are executed by the Department of Lithuanians Living Abroad which is a structural division of the ministry.

Diplomatic missions and consular offices directly subordinated to the MFA also 'engage in cultivation and strengthening of relations between Lithuanians residing in the state concerned and Lithuania'. ${ }^{3}$ Consulates provide consular services to Lithuanians living abroad. They issue documents confirming the civil status of Lithuanian citizens and provide material assistance in the event of a disease, injury, accident, or crime committed against Lithuanian citizens. They also organize voting from abroad in national, presidential, and European parliamentary elections, and referendums. Finally, consulates also issue temporary travel documents to those who lost their passports or personal identity cards.

A consultative body that operates at the government level is the Commission of the Coordination of Affairs of Lithuanians Abroad. Established in 2009, the Commission consists of the Prime Minister, the Chancellor and Deputy Chancellor of the Government, several ministers, the head of the Department of Physical Culture and Sport, the head of the Department of Lithuanians Living Abroad, the chairman of the board of the World Lithuanian Community (WLC, the main

\footnotetext{
${ }^{1}$ Lietuvos Respublikos grižimo istatymo projektas XIIIP-1130 [Proposed law for return XIIIP-1130]. Lietuvos Respublikos Seimas. 2017-09-21.

${ }^{2}$ Lietuvos Respublikos Vyriausybès nutarimas dèl Lietuvos Respublikos užsienio reikalu ministerijos nuostatu patvirtinimo Nr. 1155 [Resolution of the Government of the Republic of Lithuania on the Approval of the Statute of the Ministry of Foreign Affairs of the Republic of Lithuania No. 1155]. 1998. Valstybès žinios, 1998-09-30, No. 85-2378.

${ }^{3}$ Lietuvos Respublikos diplomatines tarnybos istatymas Nr. VIII-1012 [Law of the Republic of Lithuania on the Diplomatic Service No. VIII-1012]. 1998. Valstybès žinios, 1999-01-15, Nr. 7-140. Lietuvos Respublikos Seimas 1998-12-29.
} 
non-governmental organization representing Lithuanian communities abroad), six representatives of the WLC and a representative of the WLC in Lithuania, a representative of the Association of Municipalities and a representative of the World Lithuanians' Youth Union. ${ }^{4}$ The Commission submits proposals to the Government concerning strategic direction of state relations with Lithuanians living abroad. It also recommends how to implement the proposals, coordinates the actions of state institutions, and engages Lithuanians residing foreign countries in Lithuania's political, economic and cultural life. Finally, the Commission prepares drafts of legal acts related to Lithuanians living abroad or evaluates already existing drafts. The Government is not obliged to consult the Commission and the opinion of the Commission is not binding for the Government. It meets at least twice a year.

Another consultative body is the Commission of the Parliament of the Republic of Lithuania and the World Lithuanian Community which is the regular commission consisting of members of the Parliament and representatives of the WLC. The Commission meets twice a year and discusses issues relevant to Lithuanians residing abroad.

The Migration Information Centre (MIC) "I choose Lithuania" (lt. Renkuosi Lietuva), established in 2015 by the Vilnius Office of the International Organization for Migration and funded from the state budget, using the method of single point of contact, provides consultations to Lithuanian migrants who are returning to Lithuania, thinking about a return or anyone wishing to come to Lithuania. The MIC provides information on education, labour market, healthcare, foreign family member integration and other issues related to returning to and living in Lithuania.

Three political parties - the Liberal Movement of the Republic of Lithuania, the Homeland Union-Lithuanian Christian Democrats, and the Labour Party - established divisions in other countries with the aim to engage Lithuanians residing abroad with political activities. However, other major political parties (including those that form the present ruling coalition) do not have such divisions.

\subsubsection{Key Engagement Policies}

In Lithuania, the major strategic document which formulates diaspora engagement policies is the Global Lithuania programme, adopted in 2011 by the Resolution of the Government of the Republic of Lithuania. ${ }^{5}$ The programme sets five objectives:

\footnotetext{
${ }^{4}$ Lietuvos Respublikos Vyriausybès nutarimas dèl Užsienio lietuvių reikalų koordinavimo komisijos sudarymo Nr. 480 [Resolution of the Government of the Republic of Lithuania on the Establishment of the Commission of the Coordination of Affairs of Lithuanians Abroad No. 480]. 2018. TAR, 2018-05-22, Nr. 8209. Lietuvos Respublikos Vyriausybe 2018-05-16.

${ }^{5}$ Lietuvos Respublikos Vyriausybès nutarimas Nr. 389 dèl "Globalios Lietuvos” - užsienio lietuviu ìtraukimo i Lietuvos valstybès gyvenima - kūrimo 2011-2019 metu programos patvirtinimo [Resolution No. 389 of the Government of the Republic of Lithuania on the Approval of the "Global Lithuania" - Involvement of Lithuanians Residing Abroad into the Life of Lithuanian
} 
(1) ensure that Lithuanians abroad maintain their cultural identity in times of globalization and protect the rights of Lithuanian minorities abroad; (2) encourage Lithuanians abroad to participate in Lithuania's political, economic, scientific, cultural, and sports life; (3) strengthen the relations with the Lithuanian diaspora, encourage return migration, and transform brain drain into brain circulation; (4) create a digital platform enabling Lithuanians living abroad to communicate with people in Lithuania and; (5) encourage the diaspora to spread information about Lithuania. $^{6}$

Thirteen government agencies (including a few ministries and public agencies such as the Department of Physical Culture and Sport under the Government of the Republic of Lithuania, the Research Council of Lithuania, the National Radio and Television) are responsible for the implementation of this programme. Each year, the Government adopts an inter-institutional action plan for a 3 years specifying the activities and budget related to the programme's objectives.

The priority policy area for diaspora engagement in Lithuania is education. The Ministry of Education, Science, and Sports has a funding scheme targeted at Lithuanian schools abroad. This scheme is part of budgetary funding which is allocated by the Global Lithuania programme. ${ }^{7}$ There are nine schools which provide formal primary and secondary education to Lithuanians residing abroad and seven European schools which teach the Lithuanian language. In total, 168 schools, located all around the world, provide non-formal Lithuanian education, organizing Lithuanian language and history classes on weekends. Legal regulations also set the framework to implement the following policies (SMSM 2019): (1) state support to Lithuanians residing abroad to study in higher education schools in Lithuania ${ }^{8}$; (2) distance learning from schools located in Lithuania; (3) distance learning courses for Lithuanian language; (4) general, formal and informal education to children of exiles of Lithuanian origin provided by the Vilnius Lithuanians' House; (5) an additional point for Lithuanians residing abroad who apply to pursue their bachelor's degree in Lithuania to allow them to score higher in the general ranking of applicants (Renkuosi Lietuvą 2019).

State - Development Programme for the 2011-2019 Years Period]. 2011. Valstybès žinios, 2011-04-09, Nr. 42-1969. Lietuvos Respublikos Vyriausybe 2011-03-30.

${ }^{6}$ Ibid.

${ }^{7}$ Lietuvos Respublikos Vyriausybès nutarimas dèl „Globalios Lietuvos“ - užsienio lietuviu isitraukimo i valstybès gyvenima - kūrimo 2011-2019 metu programos igyvendinimo tarpinstitucinio veiklos plano patvirtinimo Nr. 1219 [Resolution of the Government of the Republic of Lithuania on the Approval of the Interinstitutional Action Plan of the "Global Lithuania" Involvement of Lithuanians Residing Abroad into the Life of Lithuanian State - Development Programme for the 2011-2019 Years Period No. 1219]. 2011. Valstybès žinios, 2011-10-29, Nr. 130-6150. Lietuvos Respublikos Vyriausybe 2011-10-19.

${ }^{8}$ Lietuvos Respublikos Švietimo ir mokslo ministro isakymas dèl valstybès paramos užsienio lietuviu studijoms Lietuvos aukštosiose mokyklose skyrimo tvarkos aprašo patvirtinimo Nr. V-1160 [Order by the Minister of Higher Education and Science on the Approval of the Order of State Support to Lithuanians Residing Abroad to Study in Higher Education Schools in Lithuania No. V-1160]. 2016-12-27, TAR, 2016-12-29, Nr. 29930. 
Economic policies designed to encourage the return of Lithuanian emigrants and their contributions to the economic development of the country also stand out as priority policy areas. The Ministry of Economy and Innovation and its subordinate public agencies Enterprise Lithuania and Invest Lithuania, together with social partners (e.g. NGO Global Lithuanian Leaders and others) implement a number of initiatives and projects, including the project GLL Business Advisors (encouraging Lithuanians residing abroad to advise companies and entrepreneurs in Lithuania), the Young Professionals Programme, Create Lithuania (inviting professionals with international experience to consult for public sector bodies) and the programme Work in Lithuania (encouraging Lithuanians living abroad to pursue a career in Lithuania). Finally, the annual conference Global Lithuanian Economic Forum, which brings together Lithuanians from all over the world with public authorities and independent experts to discuss the future of Lithuania, also contributes to the goal of economic progress.

The Government provides financial support (within the funding scheme of the Global Lithuania programme) to organizations of Lithuanians residing abroad, including youth organizations, preservation and return of Lithuanian cultural heritage from abroad. Projects for the dissemination of the idea of Global Lithuania in the area of culture, such as joint cultural initiatives of Lithuanians living abroad, are also funded from the state budget.

All non-resident Lithuanian citizens have the right to vote for national parliamentary and presidential elections as well as for referendums organized in the Republic of Lithuania. They are enrolled among the list of voters in the same territory in which the Parliament is located (in the case of parliamentary elections) $)^{9}$ or in the list of voters from the Vilnius city municipality (in the case of presidential elections ${ }^{10}$ and referendums $\mathrm{s}^{11}$ ). Voters can cast a ballot in consulates of the Republic of Lithuania. ${ }^{12}$ However, the law limits the right to vote and run for municipal elections because the lists of voters are made by municipalities according to the declared place of residence. ${ }^{13}$ Only those who permanently reside in Lithuania (have been staying in Lithuania for the past 90 days) can run as candidates. ${ }^{14}$ The right of Lithuanian citizens residing abroad to run for the office of the President is also

\footnotetext{
${ }^{9}$ LR Seimo rinkiu istatymas Nr. I-2721, 1992-07-09, Lietuvos Aidas, 1992-07-18, Nr. 139-0 [The Law on Elections of the Seimas of the Republic of Lithuania], the section No.33.

${ }^{10}$ LR Prezidento rinkimu istatymas Nr. I-28, 1992-12-22, Lietuvos Aidas 1992-12-29, Nr. 253-0 [The Law on Elections of the President of the Republic of Lithuania], the section No. 32.

${ }^{11}$ LR Referendumo įstatymas Nr. IX-929, 2002-06-04, Valstybès žinios, 2002-06-26, Nr. 2570 [The Law on Referendum of the Republic of Lithuania], section No. 41.

${ }^{12}$ Ibid., section No.70.

${ }^{13}$ LR Savivaldybiu tarybu rinkimu ìstatymas Nr. I-532, 1994-07-07, Valstybès žinios, 1994-07-13, Nr. 53-996 [The Law on Elections of Councils of Municipalities of the Republic of Lithuania], section No. 3.

${ }^{14}$ Ibid., section No. 3.
} 
limited: only those who have been staying in the territory of Lithuania for the past 3 years can do so. ${ }^{15}$

\subsection{Diaspora Policies and Social Protection in Lithuania}

Neither the Global Lithuania programme nor other strategic documents of the Government of Lithuania include policies focused on social protection of Lithuanians residing abroad. The absence of such a policy orientation is caused by the prevailing approach toward emigrants as potential providers of financial support rather than those who would need social assistance. Also, such policies are out of the agenda as the opportunities of the Lithuanian state to implement welfare policies in general are limited because of the relatively small public sector (government revenues and expenditures as the percentage of gross domestic product are among the lowest in the $\mathrm{EU}^{16}$ ).

Lithuanian consulates are mainly the only agencies which play a role in ensuring that Lithuanians living abroad are able to access social protection. Consulates provide information on how to access health care, pension, and family benefits and actively facilitate the exchange of necessary documents to claim these provisions. The Government does loan money in cases of death when the deceased have to be repatriated back to Lithuania. Consulates do not, however, provide any assistance in cases of unemployment, homelessness, or economic difficulties. No publiclyfunded diaspora institutions exist to provide assistance in the area of social protection. Other government institutions including ministries, play a role mostly through bilateral agreements, which simplify the rules for Lithuanian nationals residing in Russia and other countries to access social security benefits. Most of these treaties were signed after the collapse of the Soviet Union. Therefore, they reflect shared histories between the signatories rather than locations where most of the Lithuanian diaspora live.

\subsubsection{Unemployment}

Lithuania does not implement any policies directed to Lithuanians residing abroad in the area of unemployment. Only residents of Lithuania are eligible for unemployment benefits. If a person who is eligible for unemployment benefits declares his/ her departure from Lithuania, he/she loses the status of the unemployed person and the right to receive unemployment benefits in Lithuania, with the exception of the

\footnotetext{
${ }^{15}$ The Law on the Elections of the President, section No. 2.1.

${ }^{16}$ Government revenue, expenditure, and main aggregates. Eurostat. Last update: 21-01-2019. http://appsso.eurostat.ec.europa.eu/nui/submitViewTableAction.do
} 
term foreseen in the EU regulations on the coordination of social security systems. ${ }^{17}$ In order to receive unemployment benefits in Lithuania, one has to register at the territorial division of the Lithuanian Labour Exchange. For those who receive unemployment benefits while residing and seeking a job in the EU, Lichtenstein, Iceland, Norway, or Switzerland (in the cases prescribed by the EU Regulation No. $883 / 2004^{18}$ ), consulates of the Republic of Lithuania do not play any role assisting these persons to receive unemployment benefits from Lithuania.

\subsubsection{Health Care}

Before looking at the openness of the Lithuanian healthcare systems towards citizens abroad, it is important to note that consulates assist Lithuanians residing abroad in two main areas: emergency situations and access to disability payments. According to the Consular Statute, ${ }^{19}$ in cases of natural disasters, acts of terror, mass riots, war, and armed conflict, consulates have the mandate to help with the evacuation of Lithuanian nationals. In 2006, 26 Lithuanian nationals and their family members were evacuated from Lebanon when the war broke out there. Another evacuation took place in Georgia in 2008 (CARE 2010, 311). Although instances of kidnaping are not covered by the statute, in 2009, the Government also negotiated the release of five Lithuanians who were taken hostage off the ship close to the Nigerian coast (CARE 2010, 311). In addition to evacuations, consulates assist victims of violent crimes with obtaining the necessary medical, legal and translation services. ${ }^{20}$

Regarding emergency situations, Article 22 of the Consular Statute provides that Lithuanian citizens abroad are entitled to financial assistance from the state. The assistance includes funds for a person to return to Lithuania or to support oneself until repatriation is medically advisable. Any financial support must be reimbursed within 3 months of its issuance. ${ }^{21}$ Support is not provided in cash, but is instead

\footnotetext{
${ }^{17}$ Lietuvos Respublikos užimtumo istatymas Nr. XII-2470 [Law of the Republic of Lithuania on Employment No. XII-2470]. 2016. TAR, 2016-07-05, Nr. 18825. Lietuvos Respublikos Seimas 1998-12-29, section No. 4.12.

${ }^{18}$ Regulation No. 883/2004 of the European Parliament and of the Council of Europe on the coordination of social security systems. 29 April 2004. Text with relevance for the EEA and for Switzerland.

${ }^{19}$ Lietuvos Respublikos konsulinis statutas Nr. I-886. [Consular Statute of the Republic of Lithuania No. I-886]. 1995. Valstybès žinios 1995-05-09, Nr. 43-1047. Lietuvos Respublikos Seimas 1995-05-09.

${ }^{20}$ Ibid.

${ }^{21}$ Ibid., Article No.22.
} 
given to service providers. ${ }^{22}$ Consular officers determine the minimal amount needed based on the information provided by the claimant. ${ }^{23}$

It is important to note that the Lithuanian Government funds repatriations in cases unrelated to health. Specifically, since 2002, the Government has been repatriating political prisoners and exiles who moved during the Soviet occupation from the territories of the former Soviet Union to Lithuania. Measures of social support to these persons include housing, compensation of travel costs and social integration. Each year, financial resources are allocated for the implementation of this policy (e.g., 432,000 euros each for 2018, 2019, and 2020). ${ }^{24}$

In cases of death, consulates are authorized to provide the support in terms of obtaining the necessary documentation for the transportation of the remains. Municipalities where the diseased has lived bear the financial burden for the transportation costs, but only if the person was not insured and if the person's relatives by law are from low-income households. Low-income households are defined as those whose average monthly income is lower than three sizes of the guaranteed state support. ${ }^{25}$ The support is provided to the physical person requesting assistance.

When it comes to disability payments, the Consular Statute does not mention them specifically but paragraph 36 notes that consulates will assist Lithuanians living abroad with the submission and notarization of appropriate forms to receive pensions, which include disability pensions. According to paragraph 32, consular officers are also expected to meet the persons in their homes if disability or medical conditions prevent them from arriving at the consulate. ${ }^{26}$ Disability pensions are calculated differently for Lithuanians living in the EU and non-EU countries. ${ }^{27} \mathrm{In}$ the EU or countries with which Lithuania has ratified international agreements, work experience acquired in Lithuania and abroad is summed when calculating total disability pensions. If recipients work in non-EU countries, their disability payments are based solely on work experience in Lithuania.

\footnotetext{
${ }^{22}$ Isakymas Dèl Valstybès materialinès pagalbos Lietuvos Respublikos piliečiams, nukentëjusiems užsienio valstybèse, teikimo ir grąžinimo tvarkos aprašo patvirtinimo V-146 [Order regarding state financial assistance to the citizens of the Republic of Lithuania V-146]. 2018. TAR, 2018-06-11, Nr. 9670. Lietuvos Respublikos užsienio reikalu ministerija 2018-06-05.

${ }^{23}$ Ibid.

${ }^{24}$ LR Socialinès apsaugos ir darbo ministro ịsakymas dèl politiniu kaliniu ir tremtiniu bei jų šeimu nariu sugrizzimo ị Lietuva 2018-2020 metu veiksmu plano patvirtinimo, Nr. A1-447, 2017, TAR, 2017-09-18, Nr. 14777 [Order of the Minister of Social Protection and Labour on Affirmation of The Action Plan of the Repatriation of Political Prisoners and Exiles and Members of Their Families To Lithuania for Years 2018-2020, No. A1-447, 2017, TAR, 2017-09-18, Nr. 14777].

${ }^{25}$ Lietuvos Respublikos paramos mirties atveju istatymas Nr. I-348 [Law of the Republic of Lithuania on the Assistance in the Case of Death No. I-348]. 1993. Valstybès žinios, 1993-12-29, Nr. 73-1371. Lietuvos Respublikos Seimas 1993-12-23, the section No. 7.1.

${ }^{26}$ Consular Statute No. I-886 of the Republic of Lithuania, 1995.

${ }^{27}$ Lietuvos Respublikos socialinio draudimo pensiju istatymas Nr. I-549 [Republic of Lithuania Law on Social Insurance Pensions No. I-549]. 1994. Valstybès žinios, 1994-08-03, Nr. 59-1153. Lietuvos Respublikos Seimas 1994-07-18.
} 
Another distinction between the EU and non-EU residents exists in the provisions of student health insurance. According to the Health Insurance Law, ${ }^{28}$ fulltime students in institutions of higher education in other EU countries are entitled to health insurance provided by the Lithuanian state. Health insurance is not provided to students outside of the EU.

It is important to note that national health insurance in Lithuania functions as a mechanism to enforce the declarations of residencies outside Lithuania. According to the Lithuanian legislation, people going to live abroad for longer than 6 months were required to declare about their departure from 1998 to $2009 .{ }^{29}$ In 2009, the Lithuanian Government established rules that all residents shall be billed individually for health insurance rather than pay for national insurance as part of income tax. Therefore, emigrants who fail to report their departure begin accumulating health insurance debt to the state (although departure can also be declared retrospectively with proof of when the move occurred), motivating citizens to declare their actual place of residence. Whereas the issue of non-declaration of residence has been noted in many chapters in this book, Lithuania stands out as one of the states that has actively tried to prevent citizens abroad to remain covered by their home country health insurance.

The Global Lithuania programme targets the diaspora's health needs, mostly in the form of information provision. ${ }^{30}$ The Ministry of Health provides health-related information to the Lithuanian diaspora on the Ministry's website (SAM 2018). As part of the programme, the Ministry of Social Security and Labour coordinates psychological counselling for returning emigrants. In 2017, 28 consultations were held (URM 2017).

Finally, the website of the project Renkuosi Lietuva (I Choose Lithuania) provides relevant, frequently asked information. For example, it explains whether a person can obtain health insurance in one country but be treated in another. The website details useful information on how to avoid national health insurance debt. The portal is also useful for those who come to Lithuania on short visits and have to access basic health care services. In addition to publishing the information online, project coordinators enable individuals to submit questions or call by phone or Skype (Renkuosi Lietuvą 2019).

\footnotetext{
${ }^{28}$ Lietuvos Respublikos sveikatos draudimo istatymas Nr. I-1343 [Republic of Lithuania Health Insurance Law No. I-1343]. 1996. Valstybės žinios, 1996-06-12, Nr. 55-1287. Lietuvos Respublikos Seimas 1996-05-21, the section No. 6.4.7.

${ }^{29}$ Lietuvos Respublikos gyvenamosios vietos deklaravimo istatymas VIII-840 [Law regarding the declaration of the place of residency of the Republic of Lithuania VIII-840]. 2018. Valstybes žinios, 1998-07-24, Nr. 66-1910. Lietuvos Respublikos Seimas 1998-07-02.

${ }^{30}$ Resolution No. 389 of the Government of the Republic of Lithuania on the Approval of the "Global Lithuania" - Involvement of Lithuanians Residing Abroad into the Life of Lithuanian State - Development Programme for the 2011-2019 Years Period, 2011, the section No. 23.
} 


\subsubsection{Pensions}

The website of the Lithuanian Social Insurance Agency SODRA details the procedure to receive pensions while living abroad. When individuals move abroad, they are obliged to declare their departure and inform SODRA within 10 days from leaving. After submitting a request to receive pension payments abroad, these individuals are paid either in euros, or in the local currency of the country where they live if Lithuania has signed a bilateral agreement with that country. These countries include the United States of America, Canada, Belarus, and Russia. Lithuania has also a bilateral agreement with Ukraine but it transfers pension funds to the Ukrainian pension agency in euros, after which the responsible Ukrainian agency issues the pension in the local currency, hryvnia. Lithuanians in Poland also receive pensions in local currency, zloty. If a person lives in Moldova, he/she can receive a pension in euros. Pension recipients do not pay transfer fees but cover any expenses associated with the deposit of funds in their banking accounts (SODRA 2018).

Similarly as with disability benefits, consulates facilitate the receipt of pensions for Lithuanian nationals living abroad. Consulates provide information and assist with the submission and notarisation of the required documentation. ${ }^{31}$ If persons are entitled to the Lithuanian pension, they must submit a certificate, showing their place of residence. The certificate has to be renewed once a year, between the months of October and December. It can be signed by the host country institution responsible for pension provisions, a public notary in the host country or a consular officer of Lithuania. The pension recipient may submit the certificate to the Foreign Benefit Office (Užsienio išmoku tarnyba), SODRA, or the agency in the host country responsible for pensions. ${ }^{32}$

In Russia, Germany, Austria, Belarus, Ukraine, and Canada, Lithuanian nationals can address only the host country's pension agencies (SODRA 2018). In Russia, this is because the responsibility for pension payments is transferred from the Lithuanian to the Russian authorities who will continue to make pension payments. ${ }^{33}$ Although Russia is not part of the EU, the 1999 treaty establishes that totalisation of work experience acquired in Lithuania and Russia when calculating

\footnotetext{
${ }^{31}$ Consular Statute No. I-886 of the Republic of Lithuania, 1995.

${ }^{32}$ Lietuvos Respublikos socialines apsaugos ir darbo ministro iqsakymas dèl socialinio draudimo pensiju skyrimo ir mokejjimo nuostatu patvirtinimo Nr. A1-670 [Order by the Minister of Social Security and Labour of the Republic of Lithuania concerning the payment rules of social insurance and pensions, No. A1-670]. 2017. TAR, 2017-12-27, Nr. 21333. Lietuvos Respublikos socialinès apsaugos ir darbo ministerija 2017-12-27.

${ }^{33}$ Lietuvos Respublikos Vyriausybès ir Rusijos Federacijos Vyriausybès susitarimas dèl pensinio aprūpinimo [Treaty between the Republic of Lithuania and the Russian Federation regarding pension provisions]. 1999. Valstybès žinios, 2000-03-08, Nr. 20-496. Signed 1999-06-29.
} 
pension provisions. Similar rules are established in treaties with Canada, ${ }^{34}$ Belarus, ${ }^{35}$ and Ukraine. ${ }^{36}$ Other than these exceptions, pensions are summed only for EU residents. ${ }^{37}$ Pension authorities in two major EU destination countries - Austria and Germany - require all workers to address only their respective national pension agencies when submitting the life certificate rather than agencies in Lithuania based on EU Regulation No. 883. ${ }^{38}$ Consulates and other Lithuanian state institutions do not assist Lithuanian nationals accessing pension benefits provided by host countries.

In addition to consulates, other government-funded agencies also provide information on pension-related questions. The Renkuosi Lietuva (I Choose Lithuania) website gives instructions on how to acquire form E 104, which serves as proof of work experience acquired abroad, as well as examples of foreign agencies responsible for its issuance such as HM Revenue and Customs in the UK. The website also explains when people begin acquiring pensions if they worked both in Lithuania and abroad, how the pension will be paid, and whether people will receive their pensions upon returning to Lithuania (Renkuosi Lietuvą 2019).

\subsubsection{Family-Related Benefits}

Although the state of Lithuania provides monetary family benefits, Lithuanians living abroad are not eligible recipients if they do not reside in Lithuania. Nevertheless, even those outside the country's territory can have their marriages and births recognized by the Lithuanian state. A child born to Lithuanian parent(s) abroad receives a birth certificate in the country where he/she was born. In order to register the child in the Lithuanian registry and receive a passport (any child born to a Lithuanian parent is automatically granted Lithuanian citizenship), parents must submit to the nearest consulate: (1) a form requesting the child be included in the national registry; (2) a form for the transfer of personal documents; (3) foreign birth certificate;

\footnotetext{
${ }^{34}$ Lietuvos Respublikos ir Kanados sutartis dèl socialinès apsaugos [Treaty between the Republic of Lithuania and Canada regarding social security]. 2005. Valstybés žinios, 2005-12-08, Nr. 143-5186. Signed 2005-07-05.

${ }^{35}$ Lietuvos Respublikos ir Baltarusijos Respublikos sutartis dèl socialinès apsaugos [Treaty between the Republic of Lithuania and the Republic of Belarus regarding social security]. 1999. Valstybès žinios, 1999-07-14, Nr. 61-1979. Signed 1999-02-04.

${ }^{36}$ Lietuvos Respublikos ir Ukrainos sutartis del socialinès apsaugos [Treaty between the Republic of Lithuania and Ukraine regarding social security], 2001-04-23, Valstybès žinios, 2001-11-07, Nr. 93-3261.

${ }^{37}$ Lietuvos Respublikos socialinio draudimo pensiju istatymas Nr. I-549 [Republic of Lithuania Law on Social Insurance Pensions No. I-549]. 1994. Valstybès žinios, 1994-08-03, Nr. 59-1153. Lietuvos Respublikos Seimas 1994-07-18.

${ }^{38}$ Regulation No. 883 of the European Parliament and of the Council of Europe on the coordination of social security systems, 29 April 2004.
} 
(4) the child's passport in case s/he holds another citizenship; (5) marriage certificate; and (6) parents' passports or national personal identity cards. ${ }^{39}$

The foreign birth certificate and marriage certificate must be ratified with Apostille unless the child was born in the EU, Ukraine, ${ }^{40}$ Russia, ${ }^{41}$ or Moldova. ${ }^{42}$ With each of these countries, Lithuania has a bilateral agreement which establishes that any documents held official in one state are also held official in the other without any additional certification. These agreements make it possible for Lithuanians living in the listed countries to submit child registration documents without the Apostille notarization. After receiving the consular and postage fees, consulates send the documents to appropriate institutions in Lithuania and contact the parents once documents are returned.

In addition to assistance with the receipt of children's passports, consulates help Lithuanians abroad get their marriages and divorces recognized in Lithuania, and to have their names changed. The procedures are similar to the process of registering a child, and are outlined on consulates' websites (for example, see the Embassy of the Republic of Lithuania to the Kingdom of Denmark 2018). However, neither consulates nor other government institutions assist Lithuanian nationals with accessing family benefits from host countries.

The Renkuosi Lietuva (I Choose Lithuania) portal provides Lithuanians abroad with information on how their maternity or paternity benefits will be counted if they return to Lithuania after working abroad. The website also gives details on how to fill out the form E 411, which is necessary to determine which country is responsible for providing family benefits (Renkuosi Lietuvą 2019).

\footnotetext{
${ }^{39}$ Lietuvos Respublikos teisingumo ministro ìsakymas dèl civilinès būklès aktu registravimo taisykliu ir civilinès būklès aktu ịrašu ir kitu dokumentu formu patvirtinimo Nr. 1R-334 [Order by the Minister of Justice of the Republic of Lithuania regarding the rules of civil status registration or confirmation of other forms related to civil status No. 1R-334]. 2016. TAR, 2016-12-28, Nr. 29,705. Lietuvos Respublikos teisingumo ministerija 2016-12-28.

${ }^{40}$ Lietuvos Respublikos ir Ukrainos sutartis dèl teisinès pagalbos ir teisiniu santykiu civilinèse, šeimos ir baudžiamosiose bylose [Treaty between the Republic of Lithuania and the Ukraine regarding legal assistance and legal relations in civil, family, and criminal cases]. 1993. Valstybès žinios, 1994-11-25, Nr. 91-1767. Signed 1993-07-07.

${ }^{41}$ Lietuvos Respublikos ir Rusijos Federacijos sutartis dèl teisinès pagalbos ir teisiniu santykiu civilinèse, šeimos ir baudžiamosiose bylose [Treaty between the Republic of Lithuania and the Russian Federation regarding legal assistance and legal relations in civil, family, and criminal cases]. 1992. Valstybès žinios, 1995-02-10, Nr. 13-296. Signed 1992-07-21.

${ }^{42}$ Lietuvos Respublikos ir Moldovos Respublikos sutartis dèl teisinès pagalbos ir teisiniu santykiu civilinèse, šeimos ir baudžiamosiose bylose [Treaty between the Republic of Lithuania and Republic of Moldova regarding legal assistance and legal relations in civil, family, and criminal cases]. 1993. Valstybès žinios, 1995-03-03, Nr. 19-440. Signed 1993-02-09.
} 


\subsubsection{Economic Hardship}

Beyond the emergency loans mentioned above, in cases of economic difficulties or homelessness, the state of Lithuanian does not provide financial, material or any other assistance to Lithuanians residing abroad. Although diaspora organizations engage in charitable activities to assist both Lithuanians in living within and outside the country (Gudelis et al. 2015), these activities are not publicly funded.

\subsection{Conclusions}

The Government of the Republic of Lithuania has established an institutional infrastructure to implement educational, economic, cultural, and social policies for Lithuanians abroad. These policies respond to the challenges and opportunities presented by emigration and aim to protect the rights of its citizens abroad.

However, social protection of Lithuanians residing abroad is not a priority policy area for the Government of Lithuania. The Global Lithuania programme, the main strategic document shaping the Lithuanian diaspora engagement policies, does not include objectives related to the social protection of Lithuanians abroad. No publicly-funded diaspora institutions exist to provide assistance in the area of social protection. Lithuanian citizens are not eligible recipients of family, unemployment, and economic hardship benefits if they do not reside in Lithuania. This residencebased welfare system has been further reinforced by the changes in the national health insurance system which - unlike what is observed in many cases discussed in this book - pushes citizens abroad to change their residence after departure. These policy choices are a result of the view that many migrants are financially better off in high-income destination countries than in Lithuania.

Some social services for Lithuanians living abroad are provided by consulates. In cases of an injury, disease, accident, or crime committed against a citizen of the Republic of Lithuania, consulates provide the material assistance to cover expenses of the necessary medical aid, travel to Lithuania, and accommodation which has to be reimbursed later. They also facilitate the receipt of pensions for Lithuanian nationals abroad. In the area of healthcare, consulates assist Lithuanians abroad in emergency situations and with access to disability payments. However, in cases of unemployment, homelessness, or economic difficulties, the assistance is not provided to Lithuanians living abroad.

The issue of social protection of Lithuanians residing abroad has never been raised neither by public media nor by political parties or the World Lithuanian Community, although it was discussed in some policy and academic texts (Gudelis et al. 2012, 2015). The issue might be included into the agenda of policy makers in the future for further advancement of the welfare state in Lithuania. 
Acknowledgements This chapter is part of the project "Migration and Transnational Social Protection in (Post)Crisis Europe (MiTSoPro)" that has received funding from the European Research Council (ERC) under the European Union's Horizon 2020 research and innovation programme (Grant agreement No. 680014). In addition to this chapter, readers can find a series of indicators comparing national social protection and diaspora policies across 40 countries on the following website: http://labos.ulg.ac.be/socialprotection/.

\section{References}

CARE project. (2010). Consular and diplomatic protection: Legal framework in the EU member states. Project partners: Ittig-Cnr, University of Vienna, IISA. http://www.ittig.cnr.it/Ricerca/ ConsularAnd DiplomaticProtection.pdf. Accessed 5 Feb 2019.

Čiubrinskas, V. (2005). Reclaimed identity: Heritage and genealogy of the Lithuanian immigrants in Texas. Acta Historica Universitatis Klaipedensis XIX, Studia Anthropologica III.

Embassy of the Republic of Lithuania to the Kingdom of Denmark. (2018). Civiline metrikacija. https://dk.mfa.lt/dk/lt/konsuline-informacija/aktualiausia-informacija/civiline-metrikacija. Accessed 14 Apr 2018.

Gudelis, D., \& Klimavičiūte, L. (2016). Assessing global Lithuania: The strengths and weaknesses of Lithuanian diaspora engagement strategy. Journal of Baltic Studies, 47(3), 325-348.

Gudelis, D., Gečienè, I., \& Jakulevičienè, L. (2012). Lietuvos diasporos potencialo panaudojimas valstybès gerovei kurti: europos sajungos šaliu nariu geroji praktika. http://www.esparama. 1t/es_parama_pletra/failai/ESFproduktai/2012_LT_diasporos_potencialo_panaudojimas_valstybes_gerovei_kurti.pdf. Accessed 5 Feb 2019.

Gudelis, D., Gečienè, I., Nevinskaite, L., Jakulevičienè, L., Klimavičiūtė, L., \& Kanopkaitè, S. (2015). Diasporos profesionalai: kaip juos telkti kuriant Lietuvos gerovę. Vilnius: Saulelè.

Lietuviai pasaulyje. (2014). Vilnius: Lietuvos statistikos departamentas.

Renkuosi Lietuvą. (2019). Dažniausiai užduodami klausimai. http://renkuosilietuva.lt/. Accessed 5 Feb 2019.

SAM. (2018, March 13). Informacija užsienio lietuviams. http://sam.lrv.lt/lt/veiklos-sritys/informacija-uzsienio-lietuviams. Accessed 5 Feb 2019.

SMSM. (2019). Užsienio lietuvių lituanistinis švietimas. https://www.smm.lt/web/lt/smm-svietimas/informacija-atvykstantiems-is-usienio-isvykstantiems-i-uzsieni. Accessed 5 Feb 2019.

SODRA. (2018). Gaunu pensiją Lietuvoje, bet išvykstu gyventi ị užsienị. https://www.sodra.lt/ 1t/situacijos/informacija-gyventojams/gyvenantiems-ir-dirbantiems-uzsienyje/gaunu-pensijalietuvoje-bet-isvykstu-gyventi-i-uzsieni. Accessed 5 Feb 2019.

URM. (2017). 'Globalios Lietuvos' - užsienio lietuvių ịsitraukimo ị valstybès gyvenimą - kūrimo 2011-2019 m. programos tarpinstitucinio veiklos plano 2017 metų rezultatai. 1 Priedas. http:// www.urm.lt/uploads/default/documents/2017\%20m\%20\%20TVP\%20ataskaita\%20_kriterijai_\%20final.pdf. Accessed 5 Feb 2019.

Vilmorus. (2018). Užsienio lietuvių apklausa apie jų būklę ir poreikius. https://www.urm.lt/ uploads/default/documents/U\%C5\%BEsienio\%20lietuviai_suminiai\%202018.pdf. Accessed 5 Feb 2019. 
Open Access This chapter is licensed under the terms of the Creative Commons Attribution 4.0 International License (http://creativecommons.org/licenses/by/4.0/), which permits use, sharing, adaptation, distribution and reproduction in any medium or format, as long as you give appropriate credit to the original author(s) and the source, provide a link to the Creative Commons license and indicate if changes were made.

The images or other third party material in this chapter are included in the chapter's Creative Commons license, unless indicated otherwise in a credit line to the material. If material is not included in the chapter's Creative Commons license and your intended use is not permitted by statutory regulation or exceeds the permitted use, you will need to obtain permission directly from the copyright holder. 